\title{
UPAYA MEMPERTAHANKAN CAGAR BUDAYA KOTA SEMARANG MELALUI MEDIA EDUKASI
}

\author{
Dzuha Hening Yanuarsari ${ }^{1}$, Agus Setiawan ${ }^{2}$ \\ ${ }^{1,2}$ Prodi Desain Komunikasi Visual, Universitas Dian Nuswantoro \\ dzuha.yanuarsari@dsn.dinus.ac.id ${ }^{1}$, agus.setiawan@dsn.dinus.ac.id ${ }^{2}$
}

\begin{abstract}
Abstrak
Kawasan cagar budaya merupakan salah satu jenis ikonik kota yang memerlukan perhatian khusus dalam hal perawatan maupun pelestarian. Kawasan kota Semarang, merupakan salah satu kota yang memiliki banyak cagar budaya. Penelitian ini diarahkan sebagai bentuk luaran dari mata kuliah komunikasi grafis. Bentuk ilustrasi yang terinspirasi dari bangunan cagar budaya Semarang dikembangkan berdasarkan observasi pada bangunan cagar budaya kemudian dilakukan eksplorasi sketsa dilanjutkan dengan digitalisasi sebagai upaya merancang ilustrasi sebagai bahan media edukasi. Metode penelitian menggunakan metode kualitatif dengan berpijak pada observasi, literature, eksperimen, dan eksplorasi visual ilustrasi untuk mencapai desain prototipe media edukasi dalam bentuk buku ilustrasi. Data hasil observasi dan literatur disajikan secara deskriptif dan didukung dengan hasil ilustrasi. Buku ilustrasi bagian dari hasil luaran riset media edukasi yang dapat diterapkan dalam menunjang pembelajaran dan melihat seberapa besar efektifitas media dan keberadaan potensi kebertahanan cagar budaya dari sudut pandang nilai lokal genius dan sejarahnya. Penelitian ini dapat memberikan pengetahuan seputar cagar budaya beserta nilai-nilai historikalnya.
\end{abstract}

Kata Kunci: cagar budaya, media edukasi, pelestarian, Semarang

\begin{abstract}
The cultural heritage area is one of the cities iconic that require special attention in terms of care and preservation. Semarang city area is one of the cities that has many cultural reserves. This research is directed as an external form of graphic communication courses. An illustration form inspired by the Semarang heritage building was developed based on observations on the cultural heritage building then sketched exploration was continued with digitalization as an effort to design illustrations as educational media. The research method applies qualitative methods based on observation, literature, experimentation, and visual exploration to achieve the educational media prototype in the form of illustrated books. Data from observations and literature are presented descriptively and supported by illustrations. The illustrated book is the results of educational media research outputs that can be applied to support learning and see how much effectiveness the media have and the potential existence of cultural heritage from the perspective of local genius and historical values. This research can provide knowledge about cultural heritage and its historical values.
\end{abstract}

Keywords: Cultural Heritage, Educational Media, Preservation, Semarang 


\section{PENDAHULUAN}

Konsep cagar budaya telah dituangkan di dalam Undang Undang Republik Indonesia No. 11 Tahun 2010 tentang Cagar Budaya, dalam arti bahwa bentuk perhatian sudah diupayakan yaitu aksi untuk melindungi dan melestarikan cagar budaya. Keberadaan cagar budaya membawa konsekuensi dalam upaya dan cara pelestarian yang tidak hanya terpusat pada peninggalan kepurbakalaan, tetapi menyeluruh pada aspek memperhatikan unsur lingkungan yang menjadi bagian dari kawasan cagar budaya tersebut. Sudut pandang budaya dilihat dari cultural study menjadi menarik perhatian mengingat keberadaannya dalam tata ruang terdapat nilai makna kultural bagi masyarakat. Kelangsungan budaya menjadi bagian tak terpisahkan dari peradaban manusia.

Dalam ranah akademis budaya dapat menimbulkan berbagai ulasan wacana konsep dan materi. Keberadaan budaya secara pasti dapat dipahami sebagai perilaku aktualisasi ide dalam sumbangsih wujud pemikiran memberikan bentuk apresiasi dalam kehidupan masyarakat. Konsep dan pembentukan budaya dicapai melalui metode pemuasan kebutuhan rasa keindahan yang ditentukan secara budaya dan terjalin erat pula dengan aspek-aspek kebudayaan lainnya (Setiawan 2017:1). Budaya menjadi produk hasil sistem yang erat kaitannya dengan tindakan dan aktivitas dalam sistem interaksi sosial. Warna budaya nusantara sangat bervariasi dan dapat dikatakan pluralis, sehingga budaya nusantara dapat dilihat saling berhadapan. Berangkat dari hal tersebut, terdapat aspek di dalam melihat dan memperlakukan warisan budaya yaitu tiga proses interaksi yang terjadi di antaranya perlawanan atau konfrontasi, saling menyerap yaitu asimilasi hingga muncul yang baru, dan menyesuaikan diri yaitu adaptasi. Penetapan dan penyesuaian diri bisa terjadi jika memang satu budaya lebih kuat dalam daya penyesuaiannya sehingga yang dianggap baru disesuaikan dengan cara mencangkokkan dengan yang baru bila fisik tak berdaya. Upaya penyesuaian tetap dilakukan demi kelangsungan dan kebertahanan sebuah budaya, namun yang tidak bisa dilupakan adalah semangat spirit budaya tetap beradaptasi. Simbol dan ekspresi diungkapkan melaui penyesuaian diri namun kendati isi jati diri atau identitas tetap bertahan (Sutrisna 2012:36).

Cagar budaya menjadi sumber inspirasi dasar dalam perancangan media edukasi merupakan serangkaian kegiatan pembelajaran dalam mentransfer ilmu tentang kandungan lokal genius dan sejarah dapat dicapai secara interaktif sehingga "momok" tentang sejarah adalah dongeng dapat merangsang dan mengembangkan potensi mereka tentang penghayatan subtansi nilai-nilai dibalik kebertahanan cagar budaya. Media pembelajaran dipahami sebagai segala sesuatu yang diterapkan dalam mentransfer konten pesan sehingga dapat mengajak dan merangsang ide, perhatian dan penghayatan, serta keinginan anak dalam belajar dan tergerak menyelami proses belajar (Miarso, 2004). Metode pembelajaran perlu jurus jitu dan kiat-kiat untuk mengasah otak sehingga rangsangan minat melalui ilustrasi dan media yang inspiratif yaitu salah satunya melalui goresan ilustrasi. Aksi kreatifitas disertai keterampilan berperan secara menyeluruh dalam ekperimen dan eksplorasi dalam mencapai ilustrasi. Semua orang 
sesungguhnya memiliki bakat kreatif yang lebih penting dilihat dari segi pendidikan bahwa bakat kreatif bisa untuk ditingkatkan (Munandar 1999:48).

Penelitian ini mengembangkan gambar ilustrasi bertema bangunan cagar budaya Semarang yang diperoleh dari membaca fenomena sosial dan alam kemudian di analisis berdasarkan hasil observasi. Keberadaan cagar budaya perlu dirawat, dilestarikan dan dipelajari mengingat kondisi yang terus beradaptasi dengan zaman rawan sekali rapuh dan mengalami kerusakan bahkan punah. Melalui harian Solopos yang diterbitkan pada hari Minggu (24/11/2013) diberikan terdapat sekitar 101 gedung dengan bangunan tua yang terdapat di Kota Lama, dari 101 bangunan tua tersebut disebutkan bahwa sebagian besar dinyatakan tidak terawat serta mangkrak (Asfar 2013:4). Berdasarkan hal-hal yang sudah diungkapkan memicu ide dan gagasan dengan tema pelestarian bangunan cagar budaya di kota Semarang melalui kebertahanannya.

\section{METODE PENELITIAN}

Penelitian bertemakan cagar budaya kota Semarang menerapkan metode kualitatif yaitu cara penyajian secara deskriptif analisis. Penyajian data dicapai melalui observasi dan studi literatur. Sumber data berupa dokumen, literatur, dan narasumber. Peneliti bertindak sebagai alat yaitu pengamat dan melakukan wawancara secara mendalam terhadap narasumber, kajian literatur, dan pengkajian arsip (dokumentasi). Perekaman dan penjelasan keberadaan cagar budaya kota Semarang dilakukan dengan cara pemotretan dan dan sketsa didukung desangan deskripsi. tahap demi tahap dilakukan sebagai upaya mengetahui dan menjelaskan dengan data sehingga langkah yang ditempuh dapat dilihat dalam tabel 1 sebagai berikut.

Tabel 1. Tahapan Penelitian

[Sumber: Dokumentasi Dzuha \& Agus]

\begin{tabular}{|c|c|}
\hline Aspek penelitian & Capaian Temuan \\
\hline $\begin{array}{l}\text { Bangunan Cagar } \\
\text { budaya }\end{array}$ & Temuan bentuk bangunan cagar budaya \\
\hline $\begin{array}{l}\text { Cagar budaya } \\
\text { kota semarang }\end{array}$ & $\begin{array}{l}\text { - Merancang media bermuatan edukasi, dengan kandungan } \\
\text { nilai-nilai sejarah cagar budaya. } \\
\text { - Temuan berbagai wujud pengembangan gaya desain } \\
\text { ilustrasi }\end{array}$ \\
\hline $\begin{array}{l}\text { Pengembangan } \\
\text { wujud } \\
\text { penggayaan } \\
\text { desain ilustrasi }\end{array}$ & $\begin{array}{l}\text { - Ditemukan media dengan muatan edukasi dengan } \\
\text { kandungan nilai seputar cagar budaya } \\
\text { - Ditemukan bentuk pengembangan dan inovasi media } \\
\text { buku yang terinspirasi dari cagar budaya. }\end{array}$ \\
\hline \multicolumn{2}{|c|}{$\begin{array}{l}\text { Wujud pelestarian cagar budaya: pengenalan sekaligus penanaman kepada anak mengenai } \\
\text { nilai seni budaya bangsa. }\end{array}$} \\
\hline \multicolumn{2}{|c|}{ Buku ilustrasi Cagar Budaya Kota Semarang sebagai media edukasi } \\
\hline
\end{tabular}




\section{HASIL DAN PEMBAHASAN}

Pembahasan dimulai dari identifikasi cagar budaya dilanjutkan pada persoalan yang terfokus tentang ilustrasi cagar budaya kota Semarang. Selanjutnya analisis dari bahan yang dikumpulkan dilanjutkan dengan proses perancangan desain kasar ilustrasi, digitalisasi dan perancangan buku ilustrasi. Tahap selanjutnya mengimplementasikan buku ilustrasi kepada sasaran utama yaitu anak sekolah dasar. Buku ilustrasi yang sudah diimplementasikan ke dalam pembelajaran selanjutnya dievaluasi untuk mengetahui seberapa besar efek rancangan buku ilustrasi yang telah dirancang.

\subsection{Bangunan Cagar Budaya Kota Semarang}

Undang-Undang Republik Indonesia Nomor 11 tahun 2010 Pasal 1 (ayat 1) menjelaskan tentang benda cagar budaya bahwa "warisan budaya yang bersifat kebendaan, berupa benda, bangunan, struktur, dan kawasan cagar budaya baik di darat dan /atau di air yang perlu dilestarikan keberadaannya karena memiliki nilai penting bagi sejarah, ilmu pengetahuan, pendidikan, agama, dan /atau kebudayaan melalui proses penetapan."

Benda cagar budaya merupakan benda kreasi manusia, bergerak atau tidak bergerak yang berupa kesatuan atau kelompok, atau bagian-bagian atau sisa-sisanya, yang berumur sekurang-kurangnya 50 (lima puluh) tahun, atau mewakili masa gaya yang khas dan mewakili masa gaya sekurang-kurangnya 50 (lima puluh) tahun, serta dianggap mempunyai nilai penting bagi sejarah, ilmu pengetahuan, dan kebudayaan; dan benda alam yang dianggap mempunyai nilai penting bagi sejarah, ilmu pengetahuan, dan kebudayaan (UU No. 5/1992 Pasal 1)

Berikut adalah bangunan cagar budaya kota semarang yang masih dapat dijumpai hingga saat ini:

a. Masjid Kauman

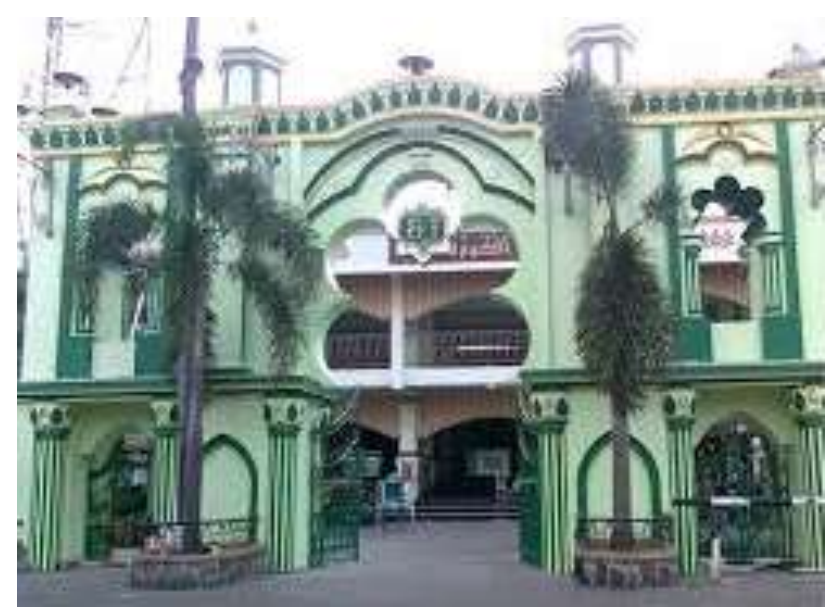

Gambar 1. Tampak Depan Masjid Kauman

[Sumber: Dokumentasi Agus Setiawan, 2018]

Masjid Kauman Semarang tercatat berdiri abad XVI Masehi (1575 M) yang dianggap keberadaan masjid kauman lebih tua dari Kota Semarang. Dalam catatan sejarah Yayasan MAS atau MBS dalam sebuah kisah, bahwa masjid agung kauman prakarsai oleh 
Sunan Pandan Arang (Ki Ageng Pandan Arang). Masyarakat Semarang menyebutnya dengan nama Pandanaran. Ki Ageng Pandan Arang sebagai sosok ulama dari Arab dengan nama Maulana Ibnu Abdul Salam. Mitos yang didapat dari silsilah ki Ageng Pandan Arang yaitu Sunan Kalijaga melalui Sultan Hadiwijoyo penguasa Pajang telah menunjuk Sunan Pandan Arang sebagai penerus atau menggantikan Syekh Siti Jenar. Sunan Pandan Arang mendapat mandat untuk syiar Islam di wilayah bagian barat Kasultanan Bintoro Demak. Sejarah nama Semarang diambil dari kata asem arang. Keberadaan masjid Agung Kauman Semarang bukanlah masjid jami pertama di Semarang, namun keterkaitan dengan komponen pembentuk kota di antaranya alunalun dan Dalem Kanjengan maka Masjid Agung Kauman paling memenuhi syarat sebagai identitas budaya kota Semarang (Priyanto 2000:2).

b. Gereja Blenduk

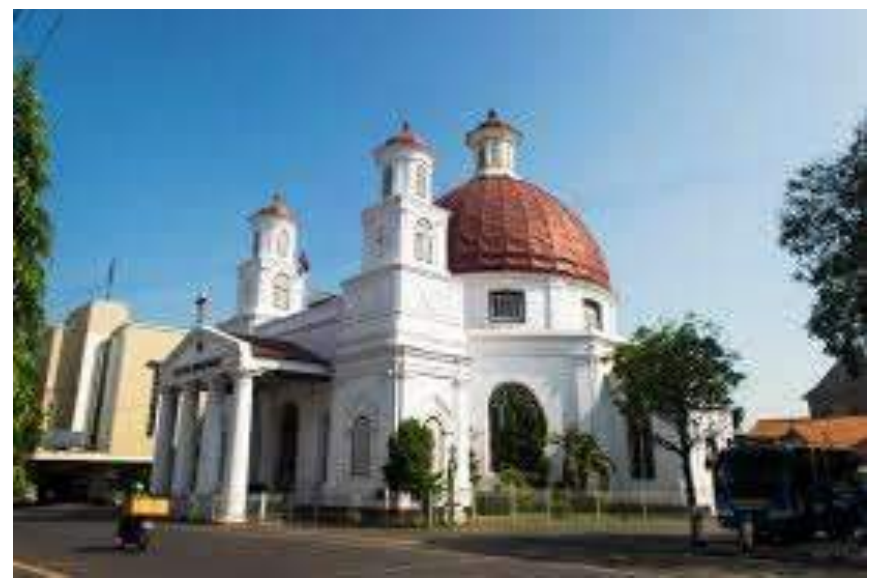

Gambar 2. Gaya Arsitektur Gereja Blenduk

[Sumber: Dokumentasi Agus Setiawan, 2018]

GPIB Immanuel Gereja Blenduk dalam sejarahnya tercatat tahun 1742 sudah berdiri. Eksistensi gereja Blenduk antara tahun 1894 hingga 1895 telah direnovasi oleh HPA de Wilde dan W. Westmaas. Gereja Blenduk mempunyai corak bentuk Eropa. Konsep Eropa pada geraja blenduk terlihat pada denah segi delapan (oktagonal). Dari sudut pandang penampilan di sisi utara, barat, Selatan dan timur membentuk corak arsitektur Pseudo Baroch. Atap bangunan dibentuk menyerupai bangunan kubah di Eropa. Keberadaan Gereja Blenduk sebagai cagar budaya telah ditetapkan dan diputuskan masuk BCB dengan Peraturan Menteri Kebudayaan dan Pariwisata No. PM.24/PW.007/MKP/2007 (Hendro 2015:23)

Istilah 'Blenduk' dalam bahasa Jawa diartikan 'membulat', jika dilihat dari wujud kubah Gereja diwujudkan membentuk bulatan. Gereja Blenduk berada di jalan Letjend Suprapto 32 Semarang. tahun 1894 sempat direnovasi W.Westman dan HPA de Wilde yaitu penambahan dua menara. Bangunan gereja Blenduk ini masih dipakai untuk kegiatan keagamaan yaitu Kebaktian setiap minggu oleh umat Nasrani. 
c. Klenteng Sam Poo Kong

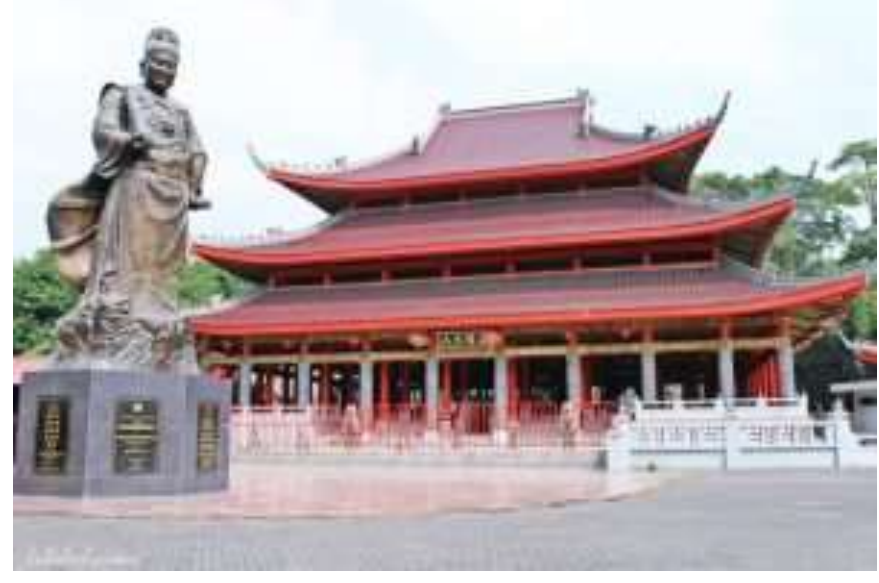

Gambar 3. Kemegahan Arsitektur Klenteng Sam Poo Kong

[Sumber: Dokumentasi Agus Setiawan, 2018]

Penampakan simbol Cina hampir mendominasi serta menghiasi sudut bangunan Klenteng Sam Po Kong. Di lihat dari sejarahnya ekspedisi Cheng Ho berasal dari daratan Cina. Keseluruhan bangunan, ritual, upacara dan ornamen di Klenteng Sam Po Kong seperti paying dewa, warna Merah dan kuning, lilin dan lapion serta hio. simbolisasi warna merah memberikan arti tersendiri yaitu tentang kegembiraan yang melambangkan manusia yang harus selalu optimis, adapun warna kuning dipahami sebagai warna kekaisaran dan lambang unsur tanah yang menggambarkan kesejahteraan hidup manusia di dunia. Ornamen dan arsitektur atap melengkung naik menunjukkan coral Tiongkok Selatan (Julianto 2015:38).

Selain simbol Cina juga terdapat simbol Islam di Klenteng Sam Po Kong yaitu terdapat makam Kyai Juru Mudi Dampo Awang. Ciri Islam didapat dari bentuk cungkup berciri khas makam Islam. Adapun, keberadaan makam Kyai dan Nyai Tumpeng juga makam Islam. Wujud fisik tidak menunjuk pada bentuk makam Islam. Namun, penyebutan Kyai dan Nyai mengacu pada gelar atau sebutan orang yang dihormati dan disegani dalam tatanan masyarakat Islam. Di sisi lain penampakan simbol Islam didapati dalam doa yang digunakan baik peziarah yang beragama Islam maupun oleh juru kunci pada makam Kyai Juru Mudi Dampo Awang, makam Kyai dan Nyai Tumpeng serta makam Kyai Jangkar (Julianto 2015).

\section{d. Lawang Sewu}

Tontjetrunay mengungkapkan, bahwa Lawang Sewu merupakan bangunan tua yang terletak di sudut jalan Pemuda persis di bundaran Tugu Muda. Gedung ini dulunya merupakan Kantor Pusat Perkeretaapian Hindia Belanda (NIS= Nederlandsch Indische Spoorweg Maatschappij) yang pertama dan terbesar. Arsitektur modern pertama di Indonesia ini merupakan hasil perancangan orang Belanda Prof. Jacob F. Klinkhamer dan BJ Queendag, yang diresmikan pada tanggal 1 Juli 1907 (Haryadi 2011:56). 


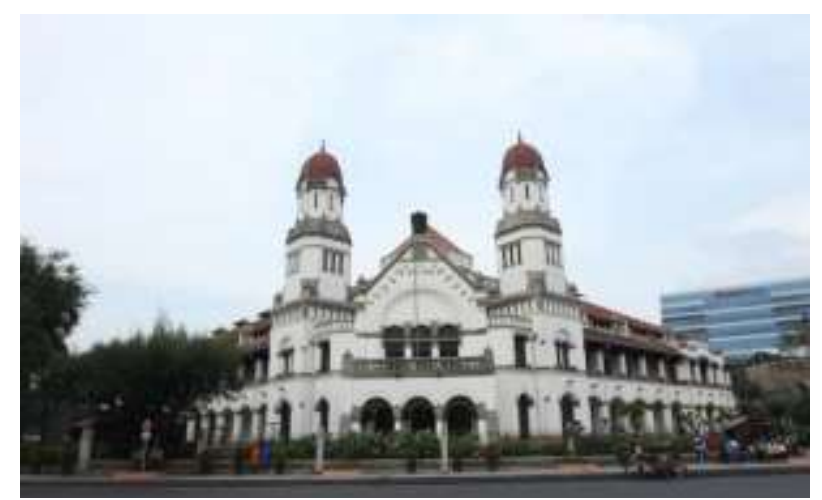

Gambar 4. Kemegahan Arsitektur Gereja Blenduk [Sumber: Dokumentasi Agus Setiawan, 2018]

Pada abad XIX Lawang Sewu dibangun oleh arsitek C. Citroen. Penamaan lawang Sewu karena memiliki banyak pintu disetiap ruang. Kompleks Lawang Sewu terbagi atas dua masa bangunan utama yaitu bangunan berbentuk $L$ berada disebelah barat kemudian di sebelah timur merupakan masa linier. Kondisi semua bangunan berlantai dua dan bercorak Romanesque Revival. Daerah pintu masuk diapit dua menara dan papa bagian atas membentuk copula persegi delapan bertudung kubah. Wujud atap limasan majemuk ditutup dengan genteng. Pintu terbuat dari Katy berdaun ganda atau dsebut pintu kupu tarung. bagian ambang jendela berbentuk lengkung dan ambang bawah tidak disangga (Hendro 2015:23). Gedung Lawang Sewu di bawah naungan PT KAI sudah direnovasi. Lawang Sewu sebagai bangunan yang unik, khas dan menarik, sehingga layak dijadikan sumber inpirasi dalam media pembelajaran.

e. Stasiun Tawang

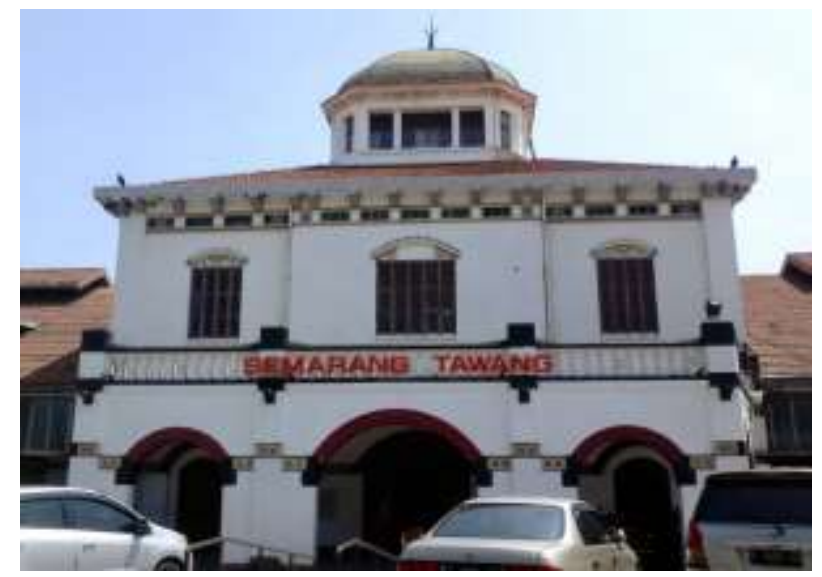

Gambar 5. Kemegahan Arsitektur Gereja Blenduk [Sumber: Dokumentasi Agus Setiawan, 2018]

Stasiun Tawang adalah stasiun kereta api yang tetap beroperasi hingga saat ini. keberadaan Stasiun Tawang telah menggantikan peran stasiun Tambak Sari milik NIS yang pertama. Pada tanggal 16 Juni 1864 secara resmi untuk melayani jalur SemarangJogja-Solo. Stasiun ini merupakan salah satu bagian komponen penting dalam pengangkutan barang maupun penumpang pada saat itu, sehingga jejak peradabannya 
mampu merekam dalam bidang transportasi perkeretaapian. Selanjutnya stasiun ini dapat menunjukkan bukti perjalan sejarah bidang transportasi pada masa era kolonial (Hendro 2015:23). Gaya arsitektur era Kolonial begitu kental sehingga dari sisi sejarah arsitektur dan desain dapat dilihat corak-corak yang membangun sebuah gedung yang memiliki keunikan dan keistimewaaan.

\subsection{Media Edukasi dalam goresan llustrasi}

Buku bergambar bagi anak khususnya pada masa belajar memiliki peran penting yaitu peran formatif dalam pendidikan. Terdapat proses interaktif yang terbangun melalui pesan dan sarana informasi yang disampaikan. Buku ilustrasi secara wujud terdiri dari buku dan ilustrasi. Buku adalah persoalan dimensi ukuran sedangkan ilustrasi lebih pada bagian dari konten dalam membangun pemahaman diantaranya coretan dengan teknik gambar, fotografi, lukisan maupun gtafis. buku ilustrasi berupa lembaran-lembaran yang disusun dan disatukan dalam sampul.

\subsubsection{Development (Pengembangan Media Edukasi)}

Pada tahap pengembangan konsep sudah bisa disusun untuk dilanjutkan pada tahap proses produksi desain untuk diwujudkan menjadi produk buku ilustrasi. Merujuk dari hasil analisis dan konsep perancangan desain, maka dibuat pemodelan produk sesuai dengan hasil/capaian yang diharapkan. Buku ilustrasi berisi seputar sejarah bangunan cagar budaya yang dipilih dengan suguhan berupa ilustrasi penggambaran isi dibuat secara ekspresif dan menarik. Dalam konsep pengembangannya menjadi materi praktik mata kuliah komunikasi grafis diperlukan usaha maksimal mahasiswa secara langsung dalam menggabungkan antara kompetensi manual dan digital yang dimiliki dengan target capaian pembelajaran yang diharapkan.

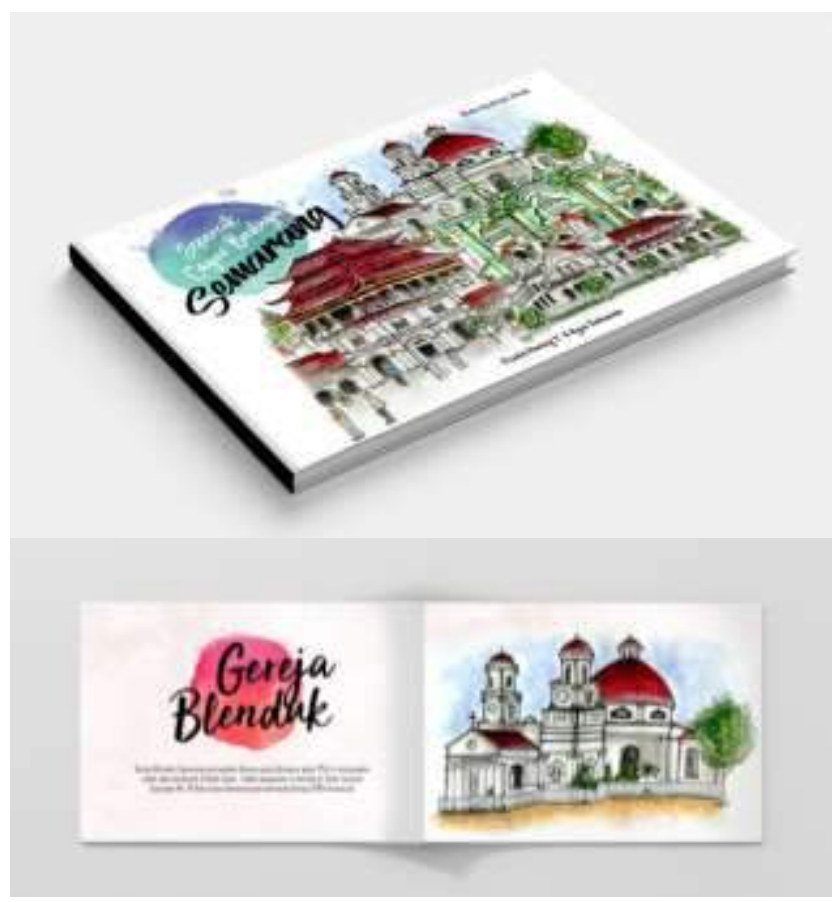

Gambar 6. Desain Pengembangan Buku Ilustrasi Cagar Budaya Semarang [Sumber: Dokumentasi Dzuha, 2018] 
Isi dari buku ilustrasi yang dibuat haruslah merupakan kombinasi antara pengumpulan data arikel yang sudah dikumpulkan dengan hasil wawancara yang telah dilakukan sehingga ketercapaian produk hasil mata kuliah komunikasi grafis dapat tersampaikan secara lebih efektif. Referensi visual dibutuhkan dalam pengembangan isi buku ilustrasi sehingga mahasiswa mampu mengkomparasikan referensi dengan hasil karya buku ilustrasinya dengan usaha yang lebiih maksimal karena sudah dilakukan riset dan observasi sebelumnya.

\subsubsection{Goresan Ilustrasi Cagar Budaya Kota Semarang}

Desain buku ilustrasi yang dibuat menggunakan desain karya sketsa ilustratif dan colourfull. Secara global penggayaan ilustratif dan ekspresif sendiri memiliki makna menggambar secara spontan dan ekspresif sehingga target sasaran buku ilustrasi yang melihat buku menjadi tertarik dan mudah memahami isi buku. Mahasiswa dalam pembuatan buku ilustrasi mereka juga harapannya mampu mengkomunikasikan bentuk visual yang tepat sehingga capaian mata kuliah yang diharapkan dapat tercapai sesuai dengan yang diharapkan.
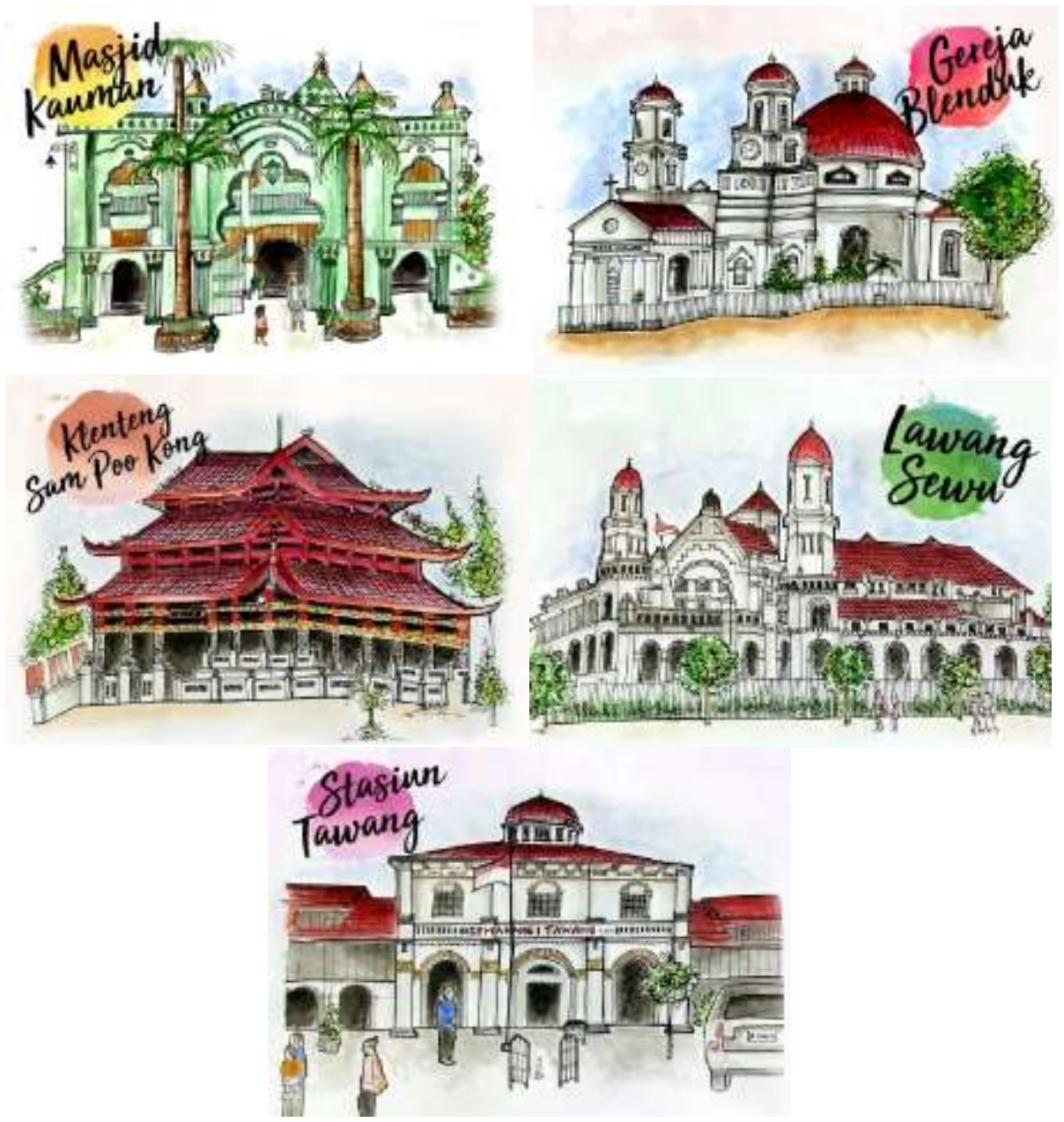

Gambar 7. Ilustrasi 5 Bangunan Cagar Budaya Semarang [Sumber: Dokumentasi Dzuha, 2018] 


\subsubsection{Implementation (Implementasi) Media edukasi sebagai wujud kebertahanan} Buku ilustrasi ini diberi judul "Sepercik Cagar Budaya Semarang". Judul ini merupakan pengembangan dari konseptualisasi tahap sebelumnya yakni gambar sketsa ilustrasi ekspresif. Isi dari buku ilustrasi ini mengenalkan setidaknya lima sejarah bangunan cagar budaya di kota Semarang. Dikarenakan target sasaran adalah anak-anak dengan mengingat sks yang ada dalam satu semester tidak terlalu banyak maka diambilah lima sub tema bangunan cagar budaya untuk isi buku ilustrasi.

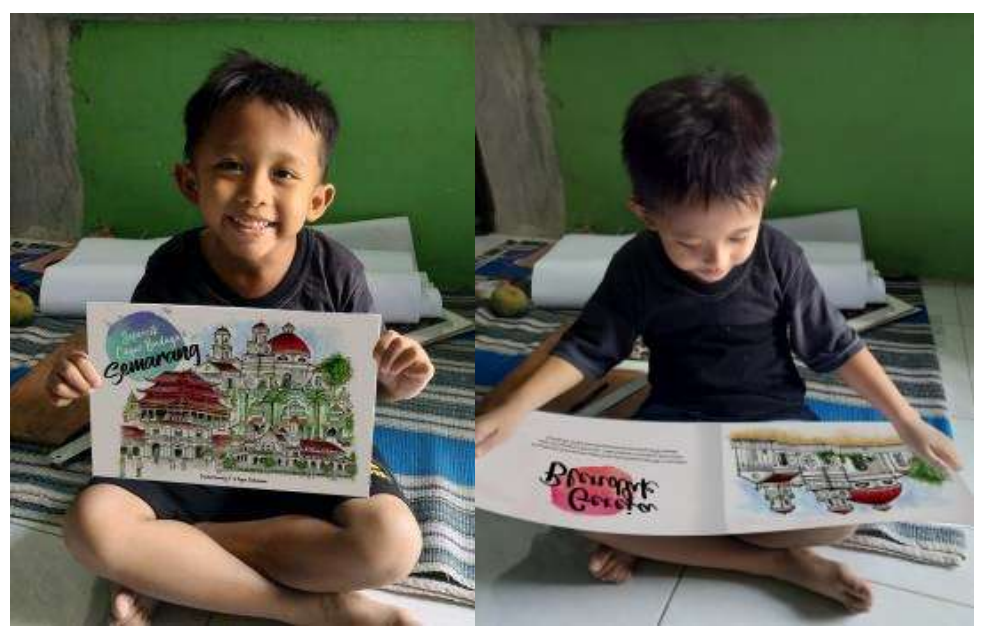

Gambar 8. Implementasi Buku Ilustrasi Cagar Budaya Pada Anak [Sumber: Dokumentasi Dzuha, 2018]

Buku ilustrasi dirancang dalam format ukuran kertas A4 $(21 \mathrm{~cm} \times 29.7 \mathrm{~cm})$, dibuat menggunakan warna yang colourfull. Pada pelayoutannya menggunakan layout bebas dengan beberapa objek gambar isi yang diwujudkan dalam bentuk ekspresif. Susunan teks dan gambar visual dibuat menyesuaikan tujuan penyampaian cerita. Tipografi memakai jenis huruf dengan model penggayaan tulisan tangan untuk memberikan kesan natural dan tidak formal. Proses penyampaian buku kepada target sasaran dibagikan secara langsung ataupun lewat pihak sekolah.

\section{KESIMPULAN}

Cagar budaya sebagai media edukasi merupakan serangkaian kegiatan pembelajaran dalam mentransfer ilmu yang harapannya dilaksanakan secara interaktif sehingga dapat mengembangkan potensi mereka dalam menyerap subtansi dalam nilai-nilai dibalik kebertahanan cagar budaya. Cagar budaya masuk dalam wilayah cultural study dapat dilihat dalam konteks pemahaman makna sehingga dalam dimensi kajian dan implementasi begitu menarik. Bangunan cagar budaya di Kota Semarang memjadi sumber inspirasi dalam merancang ilustrasi. keberlangsungan budaya bagian dari peradaban manusia dan budaya dapat dipahami sebagai proses pemikiran untuk memberi apresiasi kehidupan masyarakat. kehadiran buku ilustrasi di tengah masyarakat setidaknya memberikan kontribusi dalam mendukung gerakan litersi budaya. Hasil penelitian ini dapat dipetik pemikiran bahwa pengembangan media yang inspiratif melalui kreativitas dan ketrampilan yang dicapai melalui eksperimen berupa ilustrasi setidaknya sebagai upaya memperkuat kebertahanan cagar budaya. Cagar 
budaya dapat menjadi insprasi seorang kreator dalam mengasilkan desain ilustrasi. Hasil dari kreator dapat dikemas menjadi media edukasi yang menarik dalam menunjang proses pembelajaran.

\section{DAFTAR PUSTAKA}

Asfar, Adib. 2013. "CAGAR BUDAYA: Pemkot Semarang Didesak Bikin Perda Perlindungan Bangunan Kuno." Solopos.

Haryadi, Dwi. 2011. "Upaya Perlindungan Benda Cagar Budaya Lawang Sewu Semarang." KEADILAN PROGRESI 2(1):55-68.

Hendro, Eko Punto. 2015. "Pelestarian Kawasan Konservasi Di Kota Semarang." Jurnal Konservasi Cagar Budaya Borobudur 9(1):17-28.

Julianto, Edi Nurwahyu. 2015. "Spirit Pluralisme Dalam Klenteng Sam Po Kong Semarang." The Messenger VII(2):36-41.

Munandar, Utami. 1999. Mengembangkan Bakat Dan Kreatifitas Anak Sekolah. Jakarta: Rhineka Cipta.

Priyanto, S. 2000. Konservasi Dan Pengembangan Masjid Agung Kauman Semarang Untuk Identitas Budaya Dan Pariwisata. Semarang.

Setiawan, Agus. 2017. Eksotisme Budaya Rupa Islam Abad XVI Di Jawa. Yogyakarta: Histokultura.

Sutrisna, Deni. 2012. "Surat-Surat Melayu Beriluminasi Di Abad Ke-18 Dan Ke-19 Di Sumatra: Inspirasi Seni Motif Dan Ragam Hias Persuratan Penting Di Masa Kini." Naditira Widya 6(1):35-51. 